\title{
In remembrance of Anani Dzidzienyo (1941-2020)
}

\section{Tanya Katerí Hernández ${ }^{1}$}

Published online: 19 February 2021

๑ The Author(s), under exclusive licence to Springer Nature Limited part of Springer Nature 2021

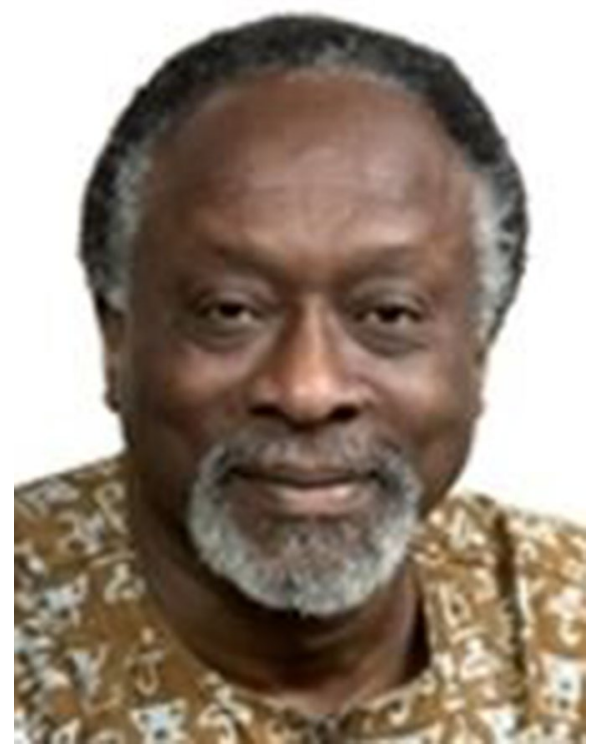

Photo credit ${ }^{1}$

With the death of Anani Dzidzienyo, Latino studies has lost one of the foundational figures in the creation of Afro-Latino studies. As a professor of Africana studies and Portuguese and Brazilian studies at Brown University for four decades, Anani guided and inspired legions of students and scholars to ask the tough questions about race and racism in Latin America and the Caribbean, and among Latinos in the United States. The explosion in attention to Afro-Latinos today was facilitated by Anani's perseverance in pushing beyond the common platitude that racial mixture in

\footnotetext{
${ }^{1}$ https://brownipc.wordpress.com/2020/10/28/remembering-professor-anani-dzidzienyo-of-africana-studi es-and-portuguese-and-brazilian-studies/
}

Tanya Katerí Hernández

ProfessorTKH@gmail.com

1 Fordham University, New York, USA 
Latin America and the Caribbean made Latin peoples inherently incapable of racism and without fixed racial identities.

His journey to centering Afro-Latinos in the study of Latinidad is worthy of note. Anani was born and educated in the Gold Coast and witnessed its transformation into an independent Ghana. He attended Williams College, and one of the most formative of his experiences there was the moment a professor shared slides of his visit to Latin America as a Fulbright professor. There, displayed on the screen, were images of Afro-Brazilian women celebrating the Afro-religious Candomblé festival of Our Lady of Bonfim. These images looked very familiar to Anani from his Gold Coast upbringing and stirred his interest in Afro-Brazilian and later Afro-Latino studies.

In 1971, collaborating with London's Minority Rights Group, Anani published his iconic article "The Position of Blacks in Brazilian Society." At the time, the article made the shocking claim that the belief that existed in the nation that the majority of Brazilians had no discrimination against Blacks was false (Dzidzienyo 1971, p. 5). It is important to note that the Brazilian ethos of the time was very much rooted in the notion that freedom from colonialism and the system of slavery it generated removed all societal racial problems. In contrast, Anani's article directly challenged that mindset with a Frantz Fanon-esque identification of how the end of colonialism and slavery did not radically restructure Brazilian society for many Afro-Brazilians.

To support his controversial premise, Anani highlighted the Portugueselanguage publications of the very few social scientists in Brazil, "who publicly expounded a view contrary to the accepted traditional, official and popular concept of race relations" (Dzidzienyo 1971, p. 10). The choice to highlight the work of the few maverick Brazilian social scientists of the time spouting the heterodoxy that racism existed in Brazil was quite political at that time-not only because it countered conventional wisdom but also because Brazilian elites and distinguished U.S. scholars had long been invested in portraying Brazil as a location with "better race relations," where racial disparities were attributed solely to economic factors (Dzidzienyo 1971, pp. 11-13).

Thereafter, Anani continued to author many articles and book chapters that pushed readers to reconsider their long-held assumptions about the "truth" of Latin American race relations (Dzidzienyo 1978). Anani's work paved the way for the development of research grounded in the realities of Afro-Latino lives by drawing on the insights of Afro-Latino scholars and researchers. This focus contrasted greatly with the traditional comparatist practice of discussing the situation of Afro-descendants without actually being in conversation with them and their own research (Dzidzienyo 1971, 1997, 1999, 2002, 2005a, b, 2007, 2011; Dzidzienyo and Turner 1981).

Moreover, he urged scholars to "insert a politically active Afro-identity into the public discourse" (Dzidzienyo 1995, p. 355). Uniquely among the U.S. comparatists, Anani also drew on Africa as an important analytical reference. In his words, the "real and imagined meanings of Africa in all its richness and contradictoriness beg to be contemplated not as aspects of a single phenomenon but as factors in the dynamics of Afro-Latin American life today" (Dzidzienyo 1995, p. 357). Anani brought this same insight to his analysis of how Latin American 
anti-Black bias influenced Latino race relations in the United States in his seminal volume, Neither Enemies nor Friends (co-edited with Suzanne Oboler).

In short, the transnational information we have today about the existence and treatment of Afro-Latino peoples is due in part to the tireless work of Anani Dzidzienyo and the generations of students he inspired to take on the complicated work of comparative race relations in the spirit of his fellow Ghanaian Kwame Nkrumah's conviction that "all people of African descent, whether they live in North or South America, the Caribbean, or in any part of the world are Africans and belong to the African nation." We at Latino Studies mourn Anani's passing but are committed to continuing his important work of illuminating the lives of Afro-Latinos within Latinidad.

\section{References}

Dzidzienyo, A. 1971. The Position of Blacks in Brazilian Society. London: Minority Rights Group.

Dzidzienyo, A. 1978. Activity and Inactivity in the Politics of Afro-Latin America. SECOLAS Annals 9 (March): 48-61.

Dzidzienyo, A. 1995. Conclusions. In No Longer Invisible: Afro Latin Americans Today, ed. Minority Rights Group, 345-358. London: Minority Rights Group.

Dzidzienyo, A. 1997. Brazilian Race Relations at the End of the 20th Century. In Race, Ethnicity and Gender: A Global Perspective, ed. S.P. Oliner and Phillip T. Gay. Dubuque: Kendall/Hunt.

Dzidzienyo, A. 1999. Africa-Brazil: "Ex Africa Semper Aliquid Novi?" In Black Brazil: Culture, Identity, and Social Mobilization, ed. Larry Crook and Randal Johnson. Los Angeles: UCLA Latin American Center.

Dzidzienyo, A. 2002. Triangular Mirrors and Moving Colonialisms. Etnográfica 6 (1): 127-140.

Dzidzienyo, A. 2005a. The Changing World of Brazilian Race Relations? In Neither Enemies nor Friends: Latinos, Blacks, Afro-Latins, ed. Anani Dzidzienyo and Suzanne Oboler, 137-156. New York: Palgrave Macmillan.

Dzidzienyo, A. 2005b. Neither Enemies nor Friends: Latinos. In Blacks, Afro-Latins, ed. Anani Dzidzienyo and Suzanne Oboler, 137-156. New York: Palgrave Macmillan.

Dzidzienyo, A. 2007. Africana Studies: The International Context and Boundaries. In A Companion to African-American Studies, ed. L.R. Gordon, and J.A. Gordon. Oxford: Blackwell Pub. Ltd.

Dzidzienyo, A. 2011. A Legacy to Brazil and the World: Remembering Abdias do Nascimento. Callaloo 34 (3): 677-681.

Dzidzienyo, A., and M.J. Turner. 1981. African-Brazilian Relations: A Reconsideration. In Brazil in the International System: The Rise of a Middle Power, ed. W.A. Selcher. New York: Routledge.

Publisher's Note Springer Nature remains neutral with regard to jurisdictional claims in published maps and institutional affiliations. 